\title{
The Emergence of the Lean Global Startup as a New Type of Firm
}

\section{Erik Stavnsager Rasmussen and Stoyan Tanev}

\author{
'A scalable startup typically requires a local") \\ population $>100$ million people. If your country \\ doesn't have that, you need to be born global. Your \\ country/industry needs a 'go global' playbook.
}

Steve Blank

Author and entrepreneur

\begin{abstract}
This article contributes to the interplay between international entrepreneurship, innovation networks, and early internationalization research by emphasizing the need to conceptualize and introduce a new type of firm: the lean global startup. It discussed two different paths in linking the lean startup and born-global internationalization strategies. The first path refers to generic lean startups that have undertaken a rapid internationalization strategy (i.e., lean-to-global startups). The second path refers to startups that have started operating on global scale since their inception and adopted the lean startup approach by seamlessly synergizing their global and lean product development activities. The article emphasizes several aspects that could be used as part of the theoretical foundation for conceptualizing lean global startups as a special new type of firm: i) the emergent nature of their business models, including the challenges of partnership development on a global scale; ii) the inherently relational nature of the global resource allocation processes; iii) the integration of the entrepreneurial, effectuation, and global marketing perspectives; iv) the need to deal with a high degree of uncertainty, including the uncertainty associated with cross-border business operations; and v) linking the ex-ante characteristics of lean startups with the ex-post characteristics of born-global firms in order to develop a technology adoption marketing perspective that considers the "crossing the chasm" process as a successful entry into a global market niche.
\end{abstract}

\section{Introduction}

"Born Global or Die Local”, as Steve Blank (2014) states, can be seen as the maxim for many new technologybased firms all over the world. At their start, a large number of these companies face the challenge of being both innovative and global at the same time. This challenge calls for the integration of two different research streams, which have until now been separate. The first stream is well established and focuses on international new ventures (Oviatt \& McDougall, 1994) or born-global firms (Knight \& Cavusgil, 1996; Rennie, 1993). The second stream is in the process of emerging and deals with the specifics of lean startups (Blank, 2013; Ries, 2011). The problems faced by lean startups and bornglobal firms during the early stages of their existence are to a large extent identical and could, from a theoret- ical point of view, be analyzed in a unified way. Many of these problems are rooted in the challenge of dealing simultaneously with early internationalization (starting or going global), business modelling, partnership relationship management, resource allocation and innovation management under conditions of multiple uncertainties right from or near their founding. Integrating the two research streams offers the opportunity to look at the empirical evidence related to new technology startups in a way that could help the emergence of a more rigorous lean startup research field as well as contribute to the articulation of business design principles that would help the conceptualization of the "lean global startup" as a new type of firm. Combining the two perspectives above gives rise to a number of interesting issues that will be discussed in this article, which starts with a summary of insights from the literat- 


\section{The Emergence of the Lean Global Startup as a New Type of Firm}

\section{Erik Stavnsager Rasmussen and Stoyan Tanev}

ure on lean startups and born-global firms, continues with a discussion focusing on the integration of the two streams, and concludes by providing a more detailed justification for the conceptualization of the lean global startup as a new type of firm.

\section{Conceptual Insights Based on a Literature Review}

The lean startup research stream and the born global/international new venture research stream arise from different traditions. Research on lean startups has been emerging from the technology-driven world with a focus on innovation, agile, and rapid product development, whereas the born-global research stems from the international business research with a focus on international operations, partnership development, marketing, and export. But, the two streams tend to share several key overlapping themes. First of all, they both seem to focus on the early stages of the business lifecycle and thus on small and medium-sized firms, and not on established multi-national corporations. Furthermore, they both focus on the entrepreneur and the founding or management team of the firm. And, from a more theoretical point view, both research streams have been inspired by both the effectuation research paradigm (Dew, Read, Sarasvathy, \& Wiltbank, 2009; Dew, Sarasathy, Read, \& Wiltbank, 2009; Sarasvathy et al. , 2014; Sarasvathy, 2001, 2008) and entrepreneurship research in general. In the next part of the article, the foundations of the two research streams will be outlined to illustrate the commonality of their theoretical backgrounds and especially of their empirical contexts.

\section{Characteristics of born-global firms and the entrepren- eurial challenges of early internationalization}

The distinctive characteristics of born-global firms can be summarized as follows (Tanev, 2012):

1. The decision of a born-global firm to engage in a systematic internationalization process is usually determined by its nature - the type of technology that is being developed or the firm's specialization within the specific industry sector, value chain, or market (Jones et al., 2011).

2. Born-global firms tend to be relatively small and have far fewer financial, human, and tangible resources as compared to large multinational enterprises that have been considered as dominant in global trade and investment.
3. Many born-global firms are technology firms, although the born-global phenomenon has been widely spread beyond the technology sector (Moen, 2002).

4. Born-global firms have managers possessing a strong international outlook and international entrepreneurial orientation. The skills of top management teams have been found to be very important for the enablement of a more intense internationalization, particularly in the knowledge-based sectors (Andersson \& Evangelista, 2006; Johnson, 2004; Loane et al., 2007).

5. Born-global firms tend to adopt differentiation strategies focusing on unique designs and highly distinctive products targeting niche markets, which may be too small for the tastes of larger firms (Cavusgil \& Knight, 2009).

6. Many born-global firms leverage information and communication technologies to identify and segment customers into narrow global market niches and skillfully serve highly specialized buyer needs. Such technologies allow them to process information efficiently and communicate with partners and customers worldwide at practically zero cost (Maltby, 2012; Servais et al., 2006).

Many born-global firms expand internationally by engaging in international direct sales or by leveraging the resources of independent intermediaries located abroad. Very often, such firms cooperate with multi-national corporations by using their existing channels, networks, and Internet infrastructure to rapidly receive substantial revenues and cash flow (Vapola et al., 2008; Vapola, 2012). Multi-national corporations may act as systems integrators or distributors of products and services of born-global firms, providing opportunities for learning, technological infrastructure access, and evolutionary growth. Recent studies have thus emphasized that the early internationalization of such firms should be considered as an innovation process in itself and that innovation and internationalization have a positive effect on each other (Zijdemans \& Tanev, 2014).

\section{The lean startup approach}

Steve Blank's introduction of the customer development process launched the lean startup movement (Blank, 2007). The Startup Owner's Manual (Blank \& Dorf, 2012) describes a step-by-step process for man- 


\section{The Emergence of the Lean Global Startup as a New Type of Firm}

\section{Erik Stavnsager Rasmussen and Stoyan Tanev}

aging the search for a new business model and provides entrepreneurs with a path from idea to a scalable business model. Blank's customer development process could be considered as a more comprehensive approach that enhances Moore's (1991) technology adoption lifecycle approach by describing the challenges of "crossing the chasm" between the early adopters and the first market niche, leading to the mainstream market. Eric Ries, a former student of Steve Blank, suggested a startup approach inspired by Blank's customer development framework (Ries, 2011). To describe his new approach he used the term "lean" from lean manufacturing to emphasize the core idea behind the methodology - the focus on eliminating waste, the non-value-creating efforts - that he saw in startups around him building products that nobody wanted. After refining and developing further the initial methodology in cooperation with startup owners, writers, and thinkers, Ries published his book The Lean Startup in 2011, thus contributing to the establishment of a lean startup terminology including the terms minimum viable product (MVP), pivoting, build-measure-learn, etc. Following the work of Ries (2011) and Blank, Eisenmann, Ries, and Dillard (2012) defined a lean startup as a firm that follows a hypothesis-driven approach to the evaluation of an entrepreneurial opportunity and the development of a new product for a specific market niche. The lean startup methodology focuses on translating a specific entrepreneurial vision into falsifiable hypotheses regarding a new product together with an associated emerging business model. The hypotheses are then tested using a series of well-thought prototypes and minimum viable products that are designed to rigorously validate specific product features or business model specifications. In this context, the entrepreneurial opportunity is based on shaping the new solution in a way that could solve a specific customer problem. The uniqueness of the methodology consists of its ability to explicitly take into account the numerous uncertainties regarding the suitability of a given solution towards a specific customer problem.

In recent years, a wide array of authors contributed to further developing the method by giving their take on the matter. Two other prominent contributors to the lean startup approach are Nathan Furr and Paul Ahlstrom (2011) with their book Nail It then Scale It. By observing both startup failures and successes, they started to see a pattern, which came to serve as the foundation of their approach. They suggested a three-step process where the entrepreneur starts with a hypothesis about the customer pain and then tests it. Once the customer pain has been identified and validated, a hypothesis about the minimum feature-set that is necessary to drive a customer purchase should be made. From there, a series of gradually more advanced prototypes should be built, while discussing and validating with customers each of the steps. Eventually, the customer solution will be "nailed", and the startup can focus on developing a go-to-market strategy and scaling the business. Other authors contributed to the original methodology by focusing on two different aspects. The first aspect is the operationalization of the lean startup approach with a focus on practical tools and frameworks. The most valuable example in this direction is the "running lean" approach by Ash Maurya (2012), which has received much attention. The second aspect is the extension of the lean startup methodology to a broader context including the management of new product design, development, and commercialization in established firms (Anthony, 2014; Arteaga \& Hyland, 2014; Furr \& Dyer, 2014).

\section{Linking the Two Research Streams}

If one takes a closer look at the two research streams, some common trends can be identified. The international new venture and born-global firm research field has its focus on how small and medium-sized enterprises can accelerate their entry into global markets, whereas lean startup research has its focus on how new entrepreneurial firms can develop new products and services and reach a large number of customers in a shorter period. Both research streams stress the complexity and the contingency of the process, the scarcity of resources, the innovation challenges, and the specific risks and uncertainties the firms have to deal with. The link between the two approaches can be found in their focus on entrepreneurship because, in both cases, the entrepreneurs have to learn to operate in complex and uncertain business ecosystems including suppliers, $\mathrm{R} \& \mathrm{D}$ partners, competitors, customers, etc. This is especially true in the case of high-tech firms, which have to be active on a global scale right from the beginning.

In several cases, technology entrepreneurship and innovation research studies have reached out to encompass themes that are typical of research focusing on born-global firms. For example, Bailetti (2012) examines how new growth-oriented technology firms can (or must) operate in a global market right from their founding. The entrepreneurs behind these technology startups must plan the internationalization of the firm in the right way from the very beginning. Moogk (2012) 


\title{
The Emergence of the Lean Global Startup as a New Type of Firm
}

\author{
Erik Stavnsager Rasmussen and Stoyan Tanev
}

discusses the lean startup concept and how entrepreneurs can apply it to the process of new technology commercialization. This is done in a context of extreme uncertainty and technology startups have to learn to design and to use minimum viable products to be able to enter a market before potential competitors. Minimum viable products offer the possibility for the technology to be tested in a way that could help the evaluation and the facilitation of a firm's global growth opportunities.

Other authors, including Tanev and colleagues (Tanev, 2012; Tanev et al., 2014), have approached the technology startup and the lean approach from the born-global context. One of their recommendations is that researchers should focus on defining startup design principles that incorporate the key attributes of bornglobal firms and use these design principles to launch and grow new technology firms. Trimi and BerbegalMirabent (2012) have discussed the emerging trends in business model design by focusing on open innovation, customer development, agile development, and lean methodologies. According to them, all these approaches converge in the use of quick iterations and the adoption of a trial-and-error philosophy for validating the hypotheses of the business model and the appropriateness of specific product or services. The logic of the lean startup model could be substantiated by combining it with specific business model frameworks that can integrate the entrepreneurial, innovation, and internationalization aspects of born-global startups (Onetti et al., 2012). The framework suggested by Onetti and colleagues (2012) defines the business model as the way a company structures its activities in determining the focus, locus, and modus of its business, where the "focus" of the business refers to the activities providing the basis of firm's value proposition (i.e., the set of activities on which the company's efforts are concentrated); the "locus" refers the location or locations across which the firms resources and value adding activities are spread (i.e., local vs. foreign based activities, inward-outward relationships, entry modes, etc.); and the "modus" refers to the specific business modes of operation with regards to the internal organization and the network design (i.e., insourcing and outsourcing of activities along social and inter-organizational ties, inward-outward relationships with other players, strategic alliances, etc.). The focus/locus/modus business model framework is one of the few that allows for accommodating the global dimension of resources, partnerships, and emerging technology markets.

There are also some distinctions between the characteristics of born-global firms and lean startups (Table 1). These distinctions offer additional opportunities for the exploration of potential synergies between the two research fields. For example, although there is a focus on

Table 1. Comparison of lean startups and born-global firms

\begin{tabular}{lll}
\hline Comparative Category & Lean Startups & Born-Global Firms \\
\hline Type of firm & Technology startups & Small and medium-sized enterprises \\
\hline Target market & New niche markets & Preexisting niche market \\
\hline $\begin{array}{l}\text { Product commercialization } \\
\text { strategy }\end{array}$ & $\begin{array}{l}\text { Technology adoption lifecycle model / } \\
\text { Crossing the chasm to address first new } \\
\text { market niche }\end{array}$ & $\begin{array}{l}\text { Global marketing approach focusing on } \\
\text { market entry strategies }\end{array}$ \\
\hline Product development focus & $\begin{array}{l}\text { New product development / Prototyping / } \\
\text { Experimentation / Agile development }\end{array}$ & $\begin{array}{l}\text { Innovative products / } \\
\text { Technology excellence }\end{array}$ \\
\hline Business model & Business model emergence & Business model development / Adoption \\
\hline $\begin{array}{l}\text { Entrepreneurship approach } \\
\text { Ofypothesis-driven entrepreneurship } \\
\text { Of key business attributes }\end{array}$ & $\begin{array}{l}\text { Exploring the value of effectual } \\
\text { entrepreneurship but focusing on causal, } \\
\text { goal-driven internationalization strategies }\end{array}$ \\
\hline
\end{tabular}




\section{The Emergence of the Lean Global Startup as a New Type of Firm}

\section{Erik Stavnsager Rasmussen and Stoyan Tanev}

niche markets as the main target of firms' products and services, the emphasis is slightly different. Whereas the lean-startup approach focuses on the challenges associated with crossing the chasm between early enthusiasts and early adopters (i.e. on developing the first substantial market niche that would validate and economically fund the development of the whole product), the research on born-global firms seems to focus on market niche entry strategies (Burgel \& Murray, 2000). The two perspectives could be integrated by considering the first market niche that would make a firm "cross the chasm" as a market niche in a global location with respect to firm's initial place of operation. In this sense, crossing the chasm for such a firm would in reality be equivalent to becoming global.

On the other hand, the lean startup approach takes a definitive new product development perspective and focuses on the challenges associated with moving across the stages of a specific technology adoption lifecycle, whereas research on born-global firms rarely discusses the challenges associated with the development of new offerings and focuses on the global marketing impact of competitive innovative products based on technological excellence or network effects. In other words, born-global firms seem to be considered in a context that is predominant about small and mediumsized enterprises, which is different from the context of a startup (Coviello, 2015). The reason for this difference is mainly historical given that the born-global concept emerged within the context of international business research focusing on retrospective studies of the process and antecedents of internationalization. Table 1 emphasizes the difference between the ex-ante and expost temporal perspectives of lean startups and bornglobal firms, respectively. It refers to the fact that lean startups operate in the anticipation of establishing a viable business model and a strong market position, whereas born-global firms are usually considered as having already established themselves in a global marketing context and benefiting from an established business model. In this sense, the challenges of linking the two research streams refer to the possibility of relating the ex-ante characteristics of lean startups to the expost characteristics of born-global firms.

For example, Bailetti and Zijdemans (2014) suggested a global value generation framework based on a dynamic resource perspective according to which the distinction between the ex-ante and ex-post value of resources. Schmidt and Keil (2012) complement the effectual entrepreneurial approach, which is typical of most technology startups, including those that global- ize rapidly under conditions of high operational, competitive, and market uncertainties (Sarasvathy et al., 2014). The global value generation framework is based on the findings of Schmidt and Keil (2012), who identified four factors or drivers that make a resource valuable to a firm ex ante: i) the firm's ex-ante market position; ii) its ex-ante resource base, which allows for complementarities; iii) its position in inter-organizational networks, which allows them to access privileged competitive information; and iv) the prior knowledge and experience of managers, which allows them to make decisions that would lead to competitive differentiation. The key contribution of Bailetti and Zijdemans (2014) was to position these four drivers in relation to the ex-post characteristics of born-global firms and offer an analytical background for future research that could further substantiate the logic of born-global technology startup success. The global value generation framework was later adopted by Zijdemans, Azimi, Tanev, and Bailetti (2015), who focused on two of the drivers that appear to be most relevant for lean startups: i) the ex-ante resource base, which allows for complementarities, and ii) the firm's position in inter-organizational networks, which allows them to access privileged competitive information. One of the key findings was that the chances of successful access to a global market niche are much higher if a startup gets hold of resources with multiple complementary effects contributing to their global market position. The findings suggest a close interrelation between intellectual property strategy, lean startup development, and global growth, which could additionally enhance the effects of resource complementarity and the access to networks resources leading to global growth. Also, it was found critical to make a distinction between upstream and downstream resources on early internationalization. This distinction provides an opportunity to discuss the complementary downstream impact of ex-ante upstream resource allocation on a global scale. Last but not least, the multiple effects of resource complementarity could be further enhanced through the upstream and horizontal affiliations of executive managers with respected scientific, technological, and professional organizations. This is an important message for science and technology-based startups interested in pursuing a global growth strategy.

\section{Conclusion}

The reflections in this article suggest several different aspects that could be used as part of the theoretical foundation for conceptualizing a lean global startup as a special new type of firm: 


\section{The Emergence of the Lean Global Startup as a New Type of Firm}

\section{Erik Stavnsager Rasmussen and Stoyan Tanev}

1. The emergent nature of their business models, where every specific business model framework is becoming just a template for the development of a viable business model.

2. The inherently relational nature of the (global) resource allocation processes.

3. The integration of the hypothesis-driven and effectual entrepreneurial perspectives.

4. The integration of the entrepreneurial, effectual, and technology marketing perspectives

5. The need to deal with the high degree of uncertainties associated with the overall business, marketing, technology innovation, and operational environment, including the uncertainty associated with cross-border business operations.

6. Linking the ex-ante characteristics of lean startups with the ex-post characteristics of born-global firms in order to develop a technology adoption marketing perspective considering the "crossing the chasm" process as a successful entry into a global market niche.

The distinction between ex-ante and ex-post perspectives (Schmidt \& Keil, 2012) is an important aspect, which offers the opportunity to discuss two different paths in linking the lean-startup and born-global strategies in new technology firms and thus helping the conceptualization of the lean global startup as a new type of firm (Tanev et al., 2015). The first path is associated with the opportunity for generic lean startups to go global by undertaking a rapid internationalization strategy. Such lean-to-global startups (L2GS) establish themselves by using a generic lean startup approach on a local or national level and then engaging in a more traditional born-global journey by exploring internationalization opportunities short after inception. The second path is associated with the opportunity for global startups - in the terminology of Oviatt and McDougall (1994) - to adopt the lean startup approach since their very inception by seamlessly synergizing their global and lean activities. It might be appropriate for such new firms to be qualified as being both lean and global from the start (Tanev, 2012) or as lean and global startups (L\&GS). One could define then the lean global startup (LGS) by using the following symbolic equation: LGS = L2GS + L\&GS.

On a more fundamental level, the conceptualization of the lean global startup is inherently related to the relational and global business aspects of new technology firms. It includes firm's ability to: i) choose the operational focus, activities, internal resources, capabilities, and assets that it is best at maximizing, and ii) look for complementary external resources and partnerships (including global resources and partners) in order to complement their specific business and operational priorities. It is exactly their specific business and operational focus that predetermines the necessity and the relational nature of their global resource allocation process. 


\section{The Emergence of the Lean Global Startup as a New Type of Firm}

\section{Erik Stavnsager Rasmussen and Stoyan Tanev}

\section{About the Authors}

Erik S. Rasmussen is an Associate Professor in the Department of Marketing and Management at the University of Southern Denmark in Odense. He received his PhD in 2001 from the University of Southern Denmark, focusing on the fast Internationalizing of Danish small and medium-sized firms. His research focuses especially on international entrepreneurship and born-global firms. In recent years, he has particularly focused on studying international entrepreneurs that can avoid domestic path dependence by establishing ventures that, from the beginning, develop routines for a multi-cultural workforce, coordinate resources across nations, and target customers in several geographic places simultaneously.

Stoyan Tanev is an Associate Professor in the Department of Technology and Innovation, Faculty of Engineering, University of Southern Denmark in Odense. He is also an Adjunct Professor in the Department of Systems and Computer Engineering at Carleton University in Ottawa, Canada, where he was previously a faculty member in the Technology Innovation Management Program. He has a MSc and a $\mathrm{PhD}$ in Physics jointly from the University Pierre and Marie Curie, Paris, France and the University of Sofia, Bulgaria, a PhD in Theology from the University of Sofia, Bulgaria, an MEng in Technology Innovation Management from Carleton University, Canada, and an MA from the University of Sherbrooke, Canada. He has multidisciplinary research interests with a focus on the fields of technology innovation management, global technology entrepreneurship, business model design and value co-creation. Dr. Tanev is Senior IEEE member, as well as member of the editorial boards of the Technology Innovation Management Review and the International Journal of Actor-Network Theory and Technological Innovation.

\section{References}

Andersson, S., \& Evangelista, F. 2006. The Entrepreneur in the Born Global Firm in Australia and Sweden. Journal of Small Business and Enterprise Development, 13(4): 642-659.

http://dx.doi.org/10.1108/14626000610705796

Anthony, S. D. 2014. The First Mile: A Launch Manual for Getting Great Ideas into the Market. Boston, MA: Harvard Business Review Press.

Arteaga, R., \& Hyland, J. 2014. Pivot: How Top Entrepreneurs Adapt and Change Course to Find Ultimate Success. Chichester,UK: John Wiley \& Sons.

Bailetti, T. 2012. What Technology Startups Must Get Right to Globalize Early and Rapidly. Technology Innovation Management Review, 2(10): 5-16.

http://timreview.ca/article/614

Bailetti, T., \& Zijdemans, E. 2014. Cybersecurity Startups: The Importance of Early and Rapid Globalization. Technology Innovation Management Review, 4(11): 14-21.

http://timreview.ca/article/845

Blank, S. 2007. The Four Steps to the Epiphany - Successful Strategies for Products that Win. Raleigh, NC: Lulu Enterprises.

Blank, S. 2013. Why the Lean Start-Up Changes Everything. Harvard Business Review, 91(5): 63-72.

Blank, S. 2014. Born Global or Die Local - Building a Regional Startup Playbook. SteveBlank.com, October 31, 2014. Accessed November 1, 2015:

http://steveblank.com/2014/10/31/born-global-or-die-localbuilding-a-regional-startup-playbook/

Blank, S. G., \& Dorf, B. 2012. The Startup Owner's Manual: The Stepby-Step Guide for Building a Great Company. Pescadero, CA: K\&S Ranch Incorporated.

Burgel, O., \& Murray, G. C. 2000. The International Market Entry Choices of Start-Up Companies in High-Technology Industries. Journal of International Marketing, 8(2): 33-62. http://dx.doi.org/10.1509/jimk.8.2.33.19624

Cavusgil, S. T., \& Knight, G. 2009. Born Global Firms: A New International Enterprise. New York, NY: Business Expert Press.

Coviello, N. 2015. Re-Thinking Research on Born Globals. Journal of International Business Studies, 46(1): 17-26.

http://dx.doi.org/10.1057/jibs.2014.59

Dew, N., Read, S., Sarasvathy, S. D., \& Wiltbank, R. 2009. Effectual Versus Predictive Logics in Entrepreneurial Decision-Making: Differences between Experts and Novices. Journal of Business Venturing, 24(4): 287-309. http://dx.doi.org/10.1016/j.jbusvent.2008.02.002

Dew, N., Sarasathy, S., Read, S., \& Wiltbank, R. 2009. Affordable Loss: Behavioral Economic Aspects of the Plunge Decision. Strategic Entrepreneurship Journal, 3(2): 105-126. http://dx.doi.org/10.1002/Sej.66

Eisenmann, T., Ries, E., \& Dillard, S. 2012. Hypothesis-Driven Entrepreneurship: The Lean Startup. Harvard Business School Entrepreneurial Management Case.

Furr, N., \& Ahlstrom, P. 2011. Nail it Then Scale it: The Entrepreneur's Guide to Creating and Managing Breaththrough Innovation. Lehi, UT: NISI Publishing. 


\section{The Emergence of the Lean Global Startup as a New Type of Firm}

\section{Erik Stavnsager Rasmussen and Stoyan Tanev}

Furr, N., \& Dyer, P. 2014. The Innovator's Method: Bringing the Lean Start-Up Into Your Organization. Boston, MA: Harvard Business Review Press.

Johnson, J. E. 2004. Factors Influencing the Early Internationalization of High Technology Start-Ups: US and UK Evidence. Journal of International Entrepreneurship, 2(1): 139-154. http://dx.doi.org/10.1023/B:JIEN.0000026910.87323.4e

Jones, M. V., Coviello, N., \& Tang, Y. K. 2011. International Entrepreneurship Research (1989-2009): A Domain Ontology and Thematic Analysis. Journal of Business Venturing, 26(6): 632-659. http://dx.doi.org/10.1016/j.jbusvent.2011.04.001

Knight, G. A., \& Cavusgil, S. T. 1996. The Born Global Firm: A Challenge to Traditional Internationalization Theory. In $\mathrm{S}$. Cavusgil \& T. Madsen (Eds.), Advances in International Marketing, 8: 11-26. Greenwich, CT: JAI Press.

Loane, S., Bell, J. D., \& McNaughton, R. 2007. A Cross-National Study on the Impact of Management Teams on the Rapid Internationalization of Small Firms. Journal of World Business, 42(4): 489-504.

http://dx.doi.org/10.1016/j.jwb.2007.06.009

Maltby, T. 2012. Using Social Media to Accelerate the Internationalization of Startups from Inception. Technology Innovation Management Review, 2(10):22-26. http://timreview.ca/article/616

Maurya, A. 2012. Running Lean: Iterate from Plan A to a Plan That Works. Sebastopol, CA: O'Reilly Media.

Moen, O. 2002. The Born Globals - A New Generation of Small European Exporters. International Marketing Review, 19(2-3): 156175. http://dx.doi.org/10.1108/02651330210425015

Moogk, D. R. 2012. Minimum Viable Product and the Importance of Experimentation in Technology Startups. Technology Innovation Management Review, 2(3):23-26.

http://timreview.ca/article/535

Onetti, A., Zucchella, A., Jones, M., \& McDougall-Covin, P. 2012. Internationalization, Innovation and Entrepreneurship: Business Models for New Technology-Based Firms. Journal of Management \& Governance, 16(3): 337-368.

http://dx.doi.org/10.1007/s10997-010-9154-1

Oviatt, B. M., \& McDougall, P. P. 1994. Toward a Theory of International New Ventures. Journal of International Business Studies, 25(1): 45-64.

http://dx.doi.org/10.1057/palgrave.jibs.8490193

Rennie, M. W. 1993. Global Competitiveness: Born Global. McKinsey Quarterly, 4: 45-52.

Ries, E. 2011. The Lean Startup: How Today's Entrepreneurs Use Continuous Innovation to Create Radically Successful Businesses. New York: Crown Business.

Sarasvathy, S., Kumar, K., York, J. G., \& Bhagavatula, S. 2014. An Effectual Approach to International Entrepreneurship: Overlaps, Challenges, and Provocative Possibilities. Entrepreneurship Theory and Practice, 38(1): 71-93.

http://dx.doi.org/10.1111/etap.12088
Sarasvathy, S. D. 2001. Causation and Effectuation: Toward a Theoretical Shift from Economic Inevitability to Entrepreneurial Contingency. The Academy of Management Review, 26(2): 243-263. http://dx.doi.org/10.2307/259121

Sarasvathy, S. D. 2008. Effectuation: Elements of Entrepreneurial Expertise. Cheltenham, UK: Edward Elgar Publishing.

Schmidt, J., \& Keil, T. 2012. What Makes a Resource Valuable? Identifying the Drivers of Firm-Idiosyncratic Resource Value. Academy of Management Review, 38(2): 206-228. http://dx.doi.org/10.5465/amr.2010.0404

Servais, P., Madsen, T. K., \& Rasmussen, E. S. 2006. Small Manufacturing Firms' Involvement in International E-business Activities. In International Marketing Research (Advances in International Marketing, Volume 17): 297-317. Bingley, UK: Emerald Group Publishing.

Tanev, S. 2012. Global from the Start: The Characteristics of BornGlobal Firms in the Technology Sector. Technology Innovation Management Review, 2(3): 5-8. http://timreview.ca/article/532

Tanev, S., Rasmussen, E., Lemminger, R., Svendsen, L. L., \& Zeidemans, E. 2014. Lean and Global Technology Start-ups: Linking the Two Research Streams. The ISPIM Americas Innovation Forum. Montreal, Canada.

Tanev, S., Rasmussen, E. S., Zijdemans, E., Lemminger, R., \& Svendsen, L. L. 2015. Lean and Global Technology Start-Ups: Linking the Two Research Streams. International Journal of Innovation Management, 19(03): 1-41.

http://dx.doi.org/10.1142/S1363919615400083

Trimi, S., \& Berbegal-Mirabent, J. 2012. Business Model Innovation in Entrepreneurship. International Entrepreneurship and Management Journal, 8(4): 449-465. http://dx.doi.org/10.1007/s11365-012-0234-3

Vapola, T., Tossavainen, P., \& Gabrielsson, M. 2008. The Battleship Strategy: The Complementing Role of Born Globals in MNC's New Opportunity Creation. Journal of International Entrepreneurship, 6(1): $1-21$.

http://dx.doi.org/10.1007/s10843-007-0018-y

Vapola, T. J. 2012. Battleship Strategy for Managing MNC-Born Global Innovation Networks. In M. Gabrielsson \& V. H. Manek Kirpalani (Eds.), Handbook of Research on Born Globals: 332-352. Cheltenham, UK: Edward Elgar.

Zijdemans, E., Azimi, Z., Tanev, S., \& Bailetti, T. 2015. Early and Rapid Globalization as Part of Innovation and Growth Strategies: Towards a Framework Supporting the Global Start of New Technology Firms. Paper presented at the R\&D Management Conference: (Fast?) Connecting R\&D, Pisa, Italy, June 23-26, 2015.

Zijdemans, E., \& Tanev, S. 2014. Conceptualizing Innovation in BornGlobal Firms. Technology Innovation Management Review, 4(9): $5-10$. http://timreview.ca/article/826 